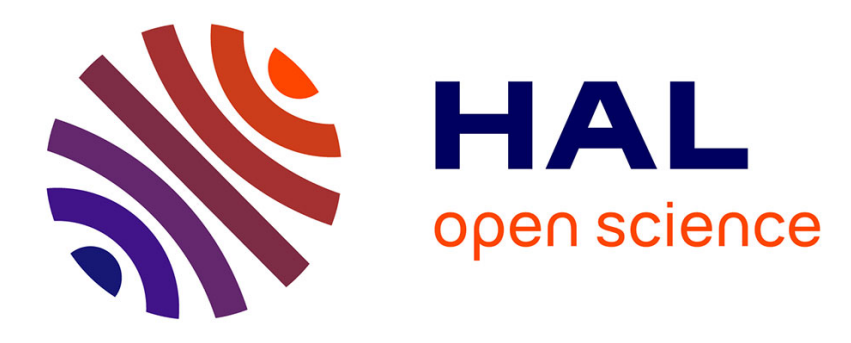

\title{
New mesophases formed by water soluble discoidal amphiphiles
}

\author{
N. Boden, R.J. Bushby, C. Hardy
}

\section{To cite this version:}

N. Boden, R.J. Bushby, C. Hardy. New mesophases formed by water soluble discoidal amphiphiles. Journal de Physique Lettres, 1985, 46 (7), pp.325-328. 10.1051/jphyslet:01985004607032500 . jpa00232518

\section{HAL Id: jpa-00232518 https://hal.science/jpa-00232518}

Submitted on 1 Jan 1985

HAL is a multi-disciplinary open access archive for the deposit and dissemination of scientific research documents, whether they are published or not. The documents may come from teaching and research institutions in France or abroad, or from public or private research centers.
L'archive ouverte pluridisciplinaire HAL, est destinée au dépôt et à la diffusion de documents scientifiques de niveau recherche, publiés ou non, émanant des établissements d'enseignement et de recherche français ou étrangers, des laboratoires publics ou privés. 
Classification

Physics Abstracts

$61.30 \mathrm{E}$

\title{
New mesophases formed by water soluble discoidal amphiphiles
}

\author{
N. Boden, R. J. Bushby and C. Hardy \\ School of Chemistry, The University, Leeds LS2 9JT, U.K.
}

(Reçu le 18 décembre 1984, accepté le 11 février 1985)

\begin{abstract}
Résumé. - Nous donnons les premiers exemples de mésophases lyotropes nématiques colonnes hexagonales, préparées par dissolution dans l'eau de mésogènes amphiphiliques non ioniques avec des molécules en forme de disque (dérivés hexa-polyethyleneoxy de triphénylène). Nous montrons que le phénomène "d'agrégation forcée par solvant " est une bonne méthode pour obtenir de nouvelles mésophases, de structures et de propriétés intermédiaires entre celles des cristaux liquides thermotropes et celles de systèmes amphiphiles lyotropes.
\end{abstract}

\begin{abstract}
We present the first examples of lyotropic discotic nematic and columnar (hexagonal) mesophases obtained by dissolution of non-ionic, disk-like amphiphilic mesogens (hexa-polyethyleneoxy derivatives of triphenylene) in water. The phenomenon of « solvent driven aggregation " is shown to be a practicable route to new and novel mesophases with structures and properties intermediate to and encompassing those of the thermotropic and lyotropic-amphiphilic classes of liquid crystals.
\end{abstract}

The fundamental structural aspect of all mesophases (liquid crystals) is the existence of long range orientational order of the constituent particles, whilst translational order is either limited or completely absent [1]. Thus, for a substance to form mesophases its constituent particles must be anisometric. For example, the low molar mass thermotropic mesophases are formed by pure substances with rod (lath) shaped molecules (nematic and smectic) [2] or disk-shaped molecules (nematic and columnar) [3], whilst the lyotropic amphiphilic mesophases are formed by rodshaped micelles (nematic and columnar) or disk-shaped micelles (nematic and lamellar) [4]. Traditionally, micelles have consisted of aggregates of soap or soap-like surfactant amphiphiles and lyotropic amphiphilic mesophases have been considered as a distinct class of liquid crystals with their own particular structures, properties, and applications [5]. These amphiphiles consist of a hydrophilic group attached to an elongated lipophilic moiety, usually an $n$-alkyl chain with typically $8<n<20$. There is, however, no a priori reason why amphiphiles with more complex symmetries cannot be synthesized. For example, it should be possible to modify the traditional thermotropic mesogen molecules into amphiphiles which will form mesophases on dissolution in a polar solvent such as water. The object of the work presented in this Letter is to demonstrate this principle. In particular, it will be shown that when polyethyleneoxy chains are substituted for the alkyl chains in the triphenylene 1a, the new mesogen molecule $1 \mathrm{~b}$, on dissolution in water, forms both nematic and columnar phases. In some ways these new triphenylene derivatives $1 \mathrm{~b}$ are 
<smiles>[X]c1cc2c3cc([X])c([X])cc3c3cc([X])c([X])cc3c2cc1[X]</smiles>

1a, $\mathrm{X}=\mathrm{CH}_{3}\left(\mathrm{CH}_{2}\right)_{n} \mathrm{O}$

lb, $\mathrm{X}=\mathrm{CH}_{3}\left(\mathrm{OCH}_{2} \mathrm{CH}_{2}\right)_{n} \mathrm{O}$

lc, $\mathrm{X}=\mathrm{CH}_{3} \mathrm{O}$

1d, $\mathrm{X}=\mathrm{HO}$

analogous to the salts of phthalocyanine-2, 9, 16, 23-tetracarboxylic acid [6] being disk-like molecules with a rigid core surrounded by hydrophilic substituents. They have, however, unique features being non-ionic and forming a nematic phase over an extensive composition range.

These $2,3,6,7,10,11$-hexa(polyethyleneoxy) derivatives of triphenylene are prepared by oxidative trimerization of veratrole [7] to give the hexamethoxy compound 1c, removal of the methyl groups with boron tribromide to give the air sensitive hexaphenol $1 \mathrm{~d}$ and alkylation using sodium hydride in dimethylsulphoxide followed by reaction with the appropriate alkyl halide.

The compound with two ethyleneoxy units in each chain (compound $1 \mathrm{~b}, n=2$ ), henceforth abbreviated $\mathrm{TP}_{6 \mathrm{EO}} \mathrm{M}$, melts at $326 \mathrm{~K}$, and does not exhibit thermotropic mesomorphism. But, on dissolution in water, both nematic and hexagonal (columnar in thermotropic terminology) phases are formed at room temperature. This is nicely illustrated by the photomicrograph in figure 1a. It shows the texture of a thin film of solution as observed under a polarizing microscope. A concentration gradient was established by allowing water to penetrate into crystalline $\mathrm{TP}_{6 \mathrm{EO}} \mathrm{M}$. A nematic phase $\mathrm{N}$ is seen to occur between what is presumed to be an isotropic micellar solution I and a hexagonal phase $\mathrm{H}$. The nematic phase is identifiable by its mobility and schlieren texture, and the hexagonal phase by its focal conic texture. The latter is more clearly illustrated in figure $1 \mathrm{c}$. Figure $1 \mathrm{~b}$ shows the pattern of textures obtained by allowing water to evaporate from the nematic phase. The hexagonal phase now exhibits a striated texture. This photomicrograph also shows a well-defined nematic-isotropic biphasic region. Examination of the effects of shear, surface and magnetic forces on the texture of the nematic phase, along the lines described in reference [8], suggest that it is of the type $\mathrm{N}_{\mathrm{C}}^{-}$, a conclusion consistent with its occurrence intermediate to the $I$ and $H$ phases [4]. Thus, this mesophase probably consists of cylindrical-shaped micelles (rods or prolate ellipsoids) with long range orientational ordering of their symmetry axes, but this is still to be verified by diffraction methods. The diamagnetic anisotropy is negative and in this respect it is similar to the thermotropic discotic nematics formed by compounds with formula 1a [3].

Deuterium n.m.r. studies, of the kind referred to in reference [9], on a sample containing $60 \%$ by wt. ${ }^{2} \mathrm{H}_{2} \mathrm{O}$, confirmed that the mesophase is diamagnetically negative. For this sample, $T_{\mathrm{NI}}=295 \mathrm{~K}$ and the width of $\mathrm{N}-\mathrm{I}$ biphasic region is approximately $0.8 \mathrm{~K}$ which is similar to that for the $\mathrm{N}_{\mathrm{D}}^{+}$(disk-shaped micelles) phase formed in mixtures of caesium perfluoro-octanoate and water [9]. The n.m.r. experiments also show that macroscopically aligned samples of the hexagonal phase can be obtained by cooling from the corresponding aligned nematic phase. This is important for future studies and exploitation of these mesophases.

A preliminary investigation shows that the nematic phase exists in mixtures containing between 50 to $90 \%$ by wt. water and between 300 to $289 \mathrm{~K}$ at 1 atmosphere. This is a much more extensive composition range than for any previously reported $\mathrm{N}_{C}$ phase [11]; in fact, it encompasses the entire range of compositions in which such phases have previously been observed. In this respect it compares with the $\mathrm{N}_{\mathrm{D}}^{+}$mesophase of the caesium perfluoro-octanoate system (37 to $78 \%$ by wt. water). For both these systems the nematic phase is stable for volume fractions of amphiphile 
(a)

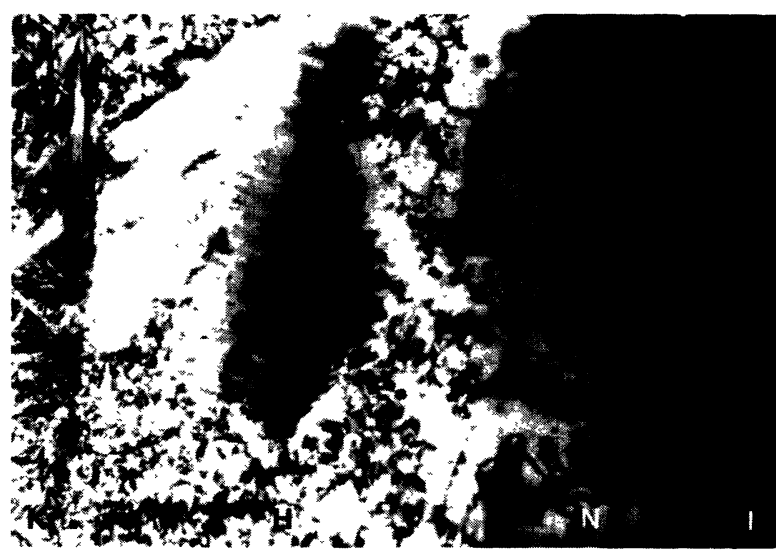

(b)

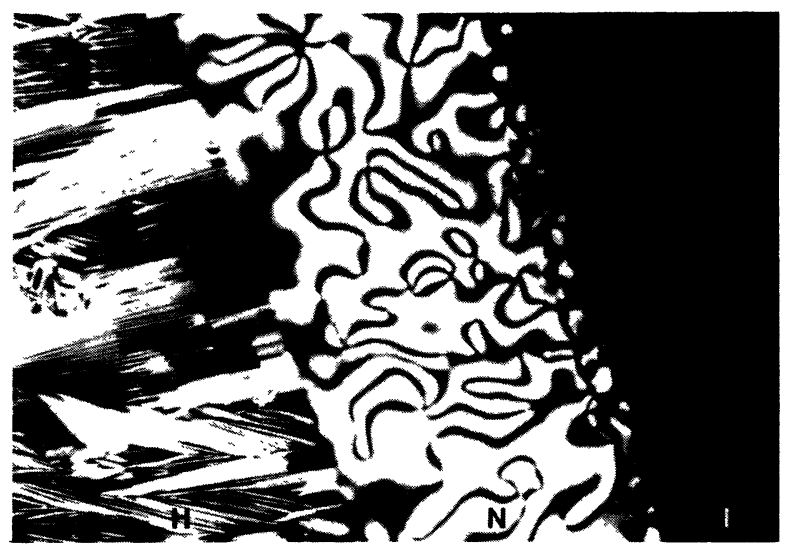

(c)

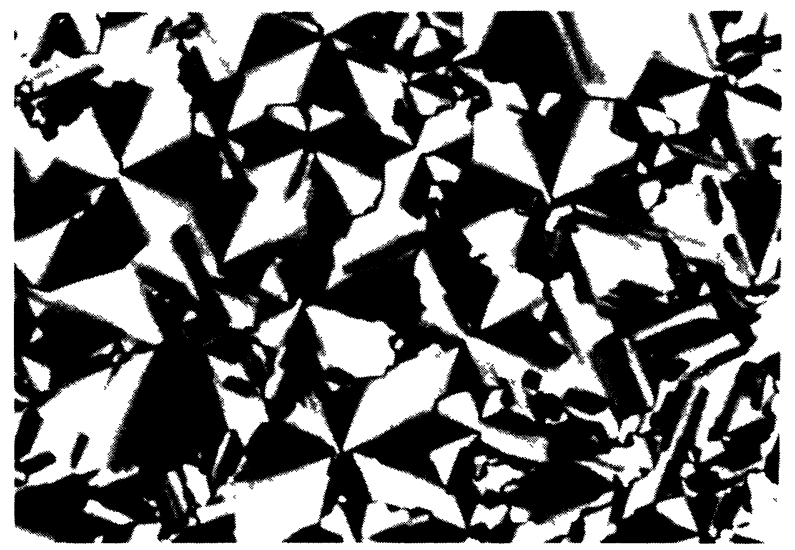

Fig. 1. - Photomicrographs of textures observed in $\mathrm{TP}^{2} \mathrm{EO}_{2} \mathrm{M}$-water mixtures at room temperature and with magnification $\times 100:$ (a) sequence of phases observed when a concentration gradient is established by allowing water to penetrate into an array of crystals; (b) as in (a), but concentration gradient established by allowing water to evaporate out of the sample cell ; (c) focal conic texture of hexagonal phase (magnification $\times 200$ ). Nomenclature : K, crystal; H, hexagonal phase; N, nematic phase; I, isotropic micellar solution. 
between 0.1 to 0.4 . The extensive composition range for the caesium perfluoro-octanoate-water system arises because the hydrophilicity of the fluorocarbon chain prohibits the formation of cylindrical micelles at high water contents. In contrast, the topology of the TP6EO $\mathrm{M}$ amphiphile precludes the formation of bilayer micelles and hence the hexagonal to lamellar phase transition, usually observed on increasing $\phi_{\mathrm{A}}$, is prohibited. Thus, this system provides the long sought after model system required for studies of order-disorder transitions and intermicellar interactions in concentrated micellar solutions. Moreover, this is, to our knowledge, the first reported observation of a nematic phase in a simple two component non-ionic amphiphile-water system.

Finally, we wish to emphasize the practical utility of the phenomenon of "solvent driven aggregation " which has been demonstrated herein. It should be applicable to a wide variety of organic structures and could be used to produce a new generation of novel mesophases with interesting structures, properties and applications. Additionally, the mesogenic amphiphile (mesophile) could be designed so that the ordered arrays of aggregates can be chemically crosslinked and so lead to the production of ordered polymer films or fibres. This approach is complementary to the use of liquid crystalline polymers for this purpose.

\section{Acknowledgments.}

We thank J. Ahmed, S. A. Corne and L. Ferris for their assistance with various aspects of this work and the Science and Engineering Research Council for financial support.

\section{References}

[1] De Gennes. P. G., The Physics of Liquid Crystals (Oxford Univ. Press) 1974.

[2] Gray, G. W., in Liquid Crystals : Their Physics, Chemistry and Applications Eds., C. Hilsum, and E. P. Raynes (The Royal Soc. of London) 1983, pp. 77-92.

[3] Destrade, C., Gasparoux, H., Foucher, P., Nguyen Huu Tinh, Malthete, J. and Jacques, J., J. Chim. Phys. 80 (1983) 137.

[4] Boden, N., Radley, K. and Holmes, M. C., Mol. Phys. 42 (1981) 493.

[5] TIDDY, G. J. T., Phys. Rep. 57 (1980) 7 ;

Pershan, P. S., Physics Today (1982) 34.

[6] Gaspard, S., Hochapfel, A., Viovy, R., C.R. Hebd. Séan. Acad. Sci. Paris. Sér. C 289 (1979) 387.

[7] Matheson, I. M., Musgrave, O. C. and Webster, C. J., Chem. Commun. 278 (1965).

[8] Boden, N., Radley, K. and Holmes, M. C., Mol. Cryst. Liq. Cryst. 100 (1983) 93.

[9] Boden, N., Jackson, P. H., McMullen, K. and Holmes, M. C., Chem. Phys. Lett. 65 (1979) 476.

[10] Boden, N. and Holmes, M. C., Chem. Phys. Lett. 109 (1984) 76.

[11] Lawson, K. D. and Flautt, T. J., J. Am. Chem. Soc. 89 (1967) 5489 ;

Long, R. C. and Goldstein, J. H., Mol. Cryst. Liq. Cryst. 23 (1973) 137 ;

see also reviews by Forrest, B. J. and ReEVES, L. W., Chem. Rev. 81 (1981) 1 ;

SAUPE, A., Nuovo Cimento 30 (1984) 16. 